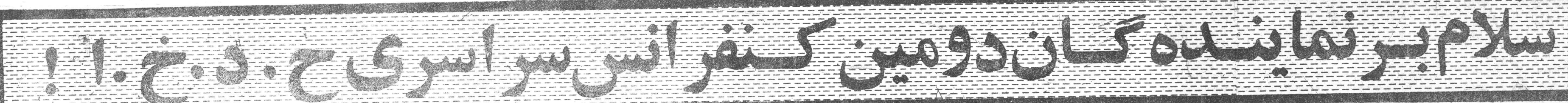

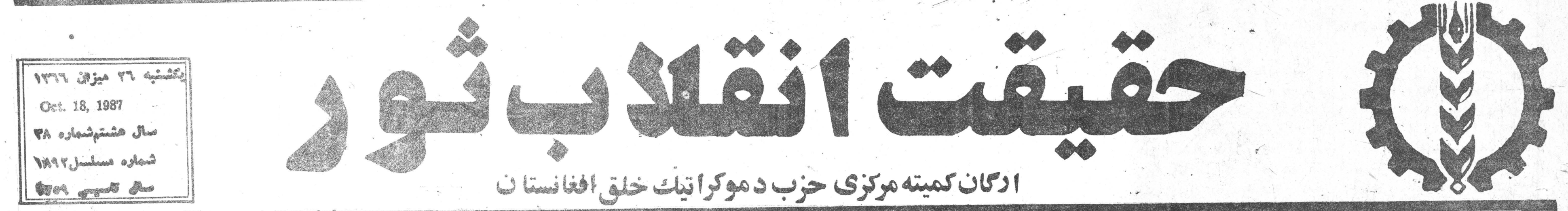

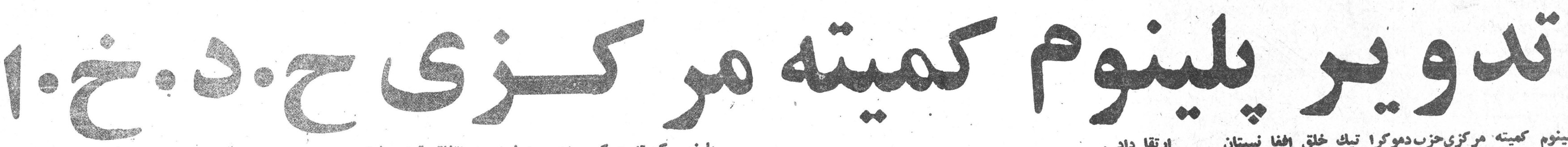
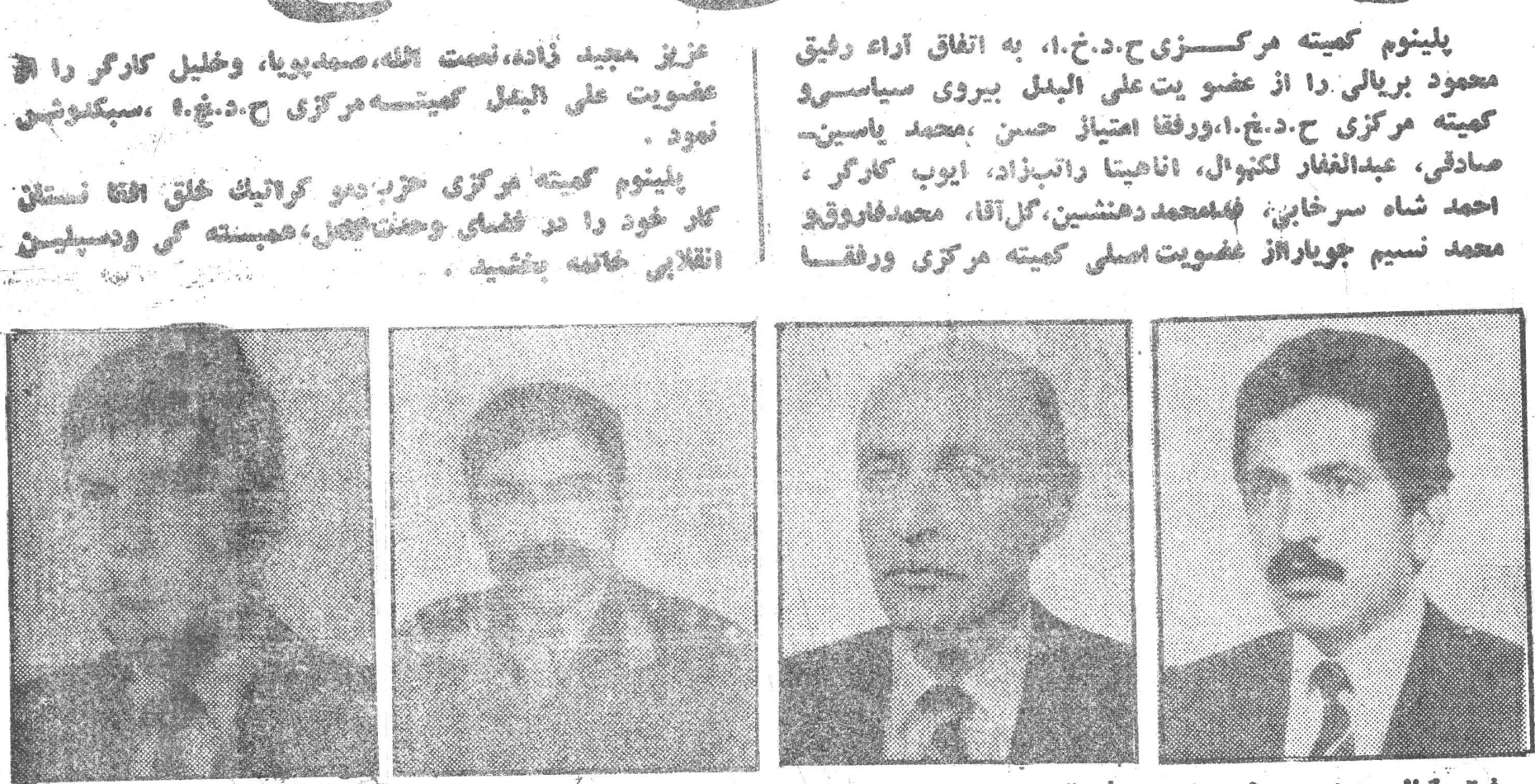

L L

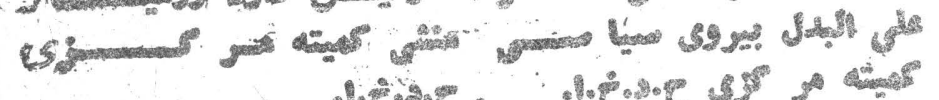

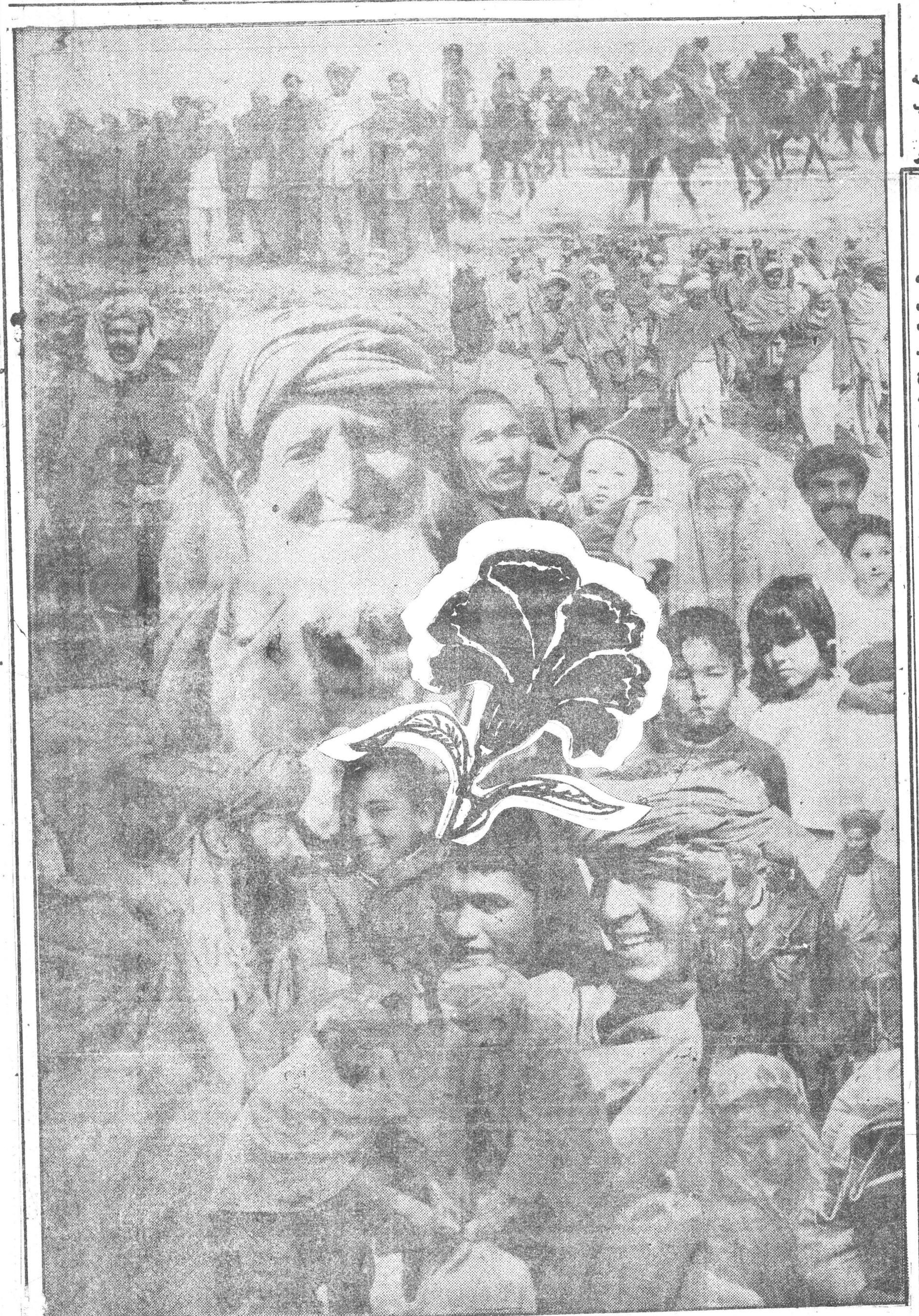

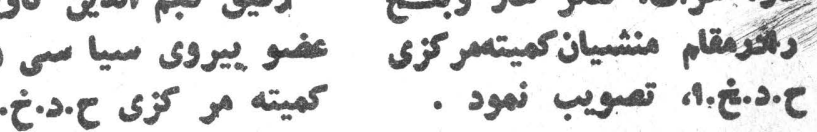

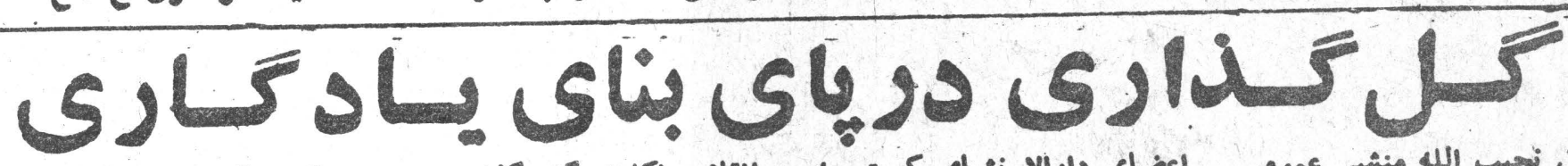

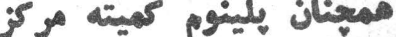

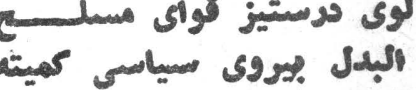

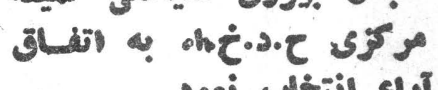

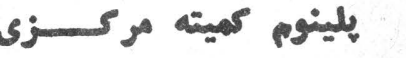

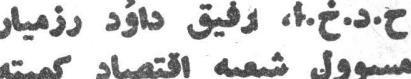

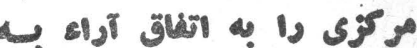

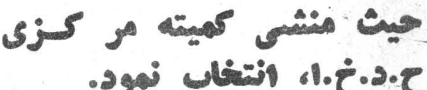

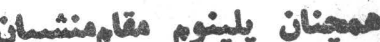
كميته ماى هزبم ولايات كندي

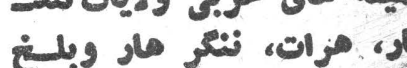

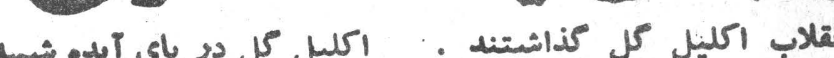

\section{$\left.15 \int^{\circ}\right)^{\circ}$}

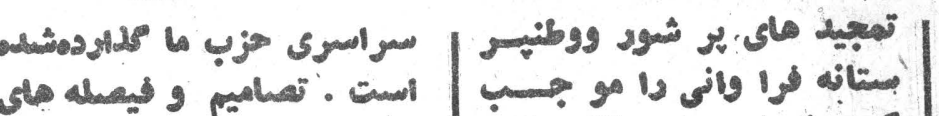

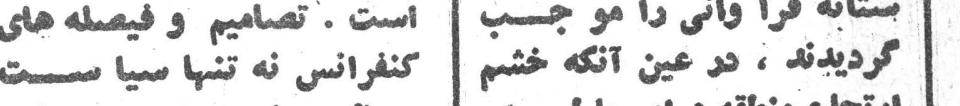

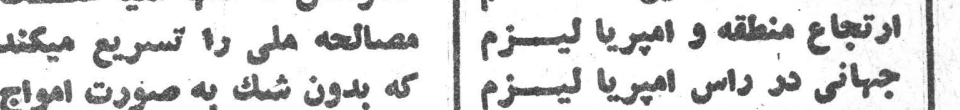

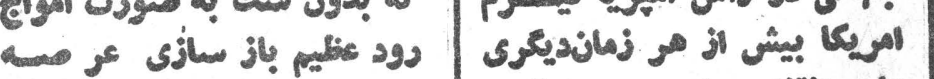

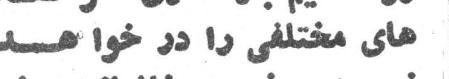

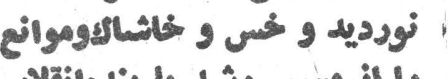

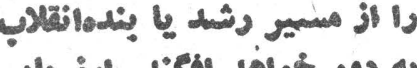

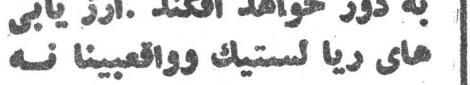

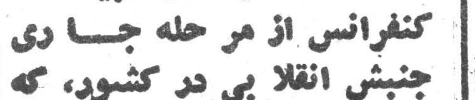

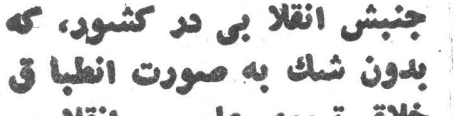

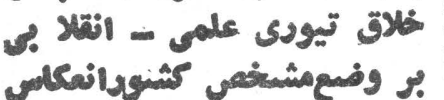

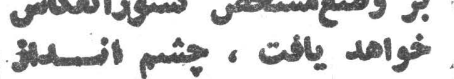

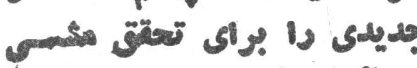

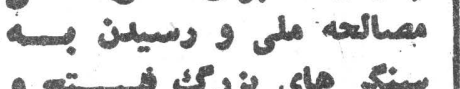

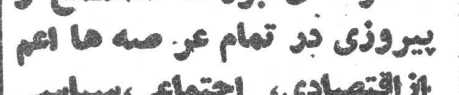

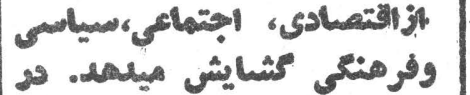

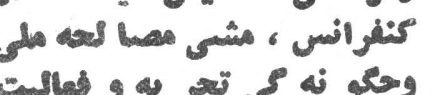

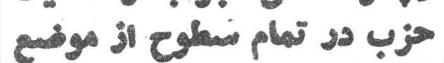

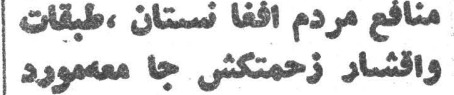

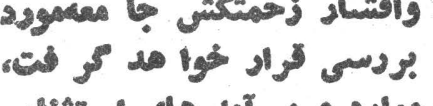

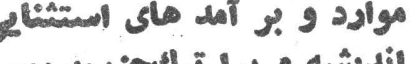

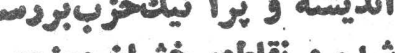

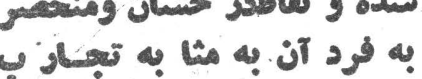

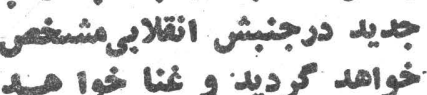

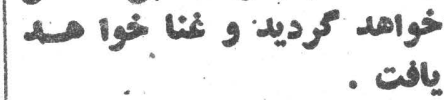

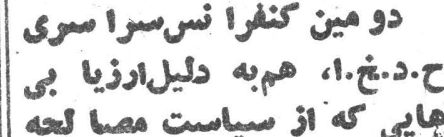

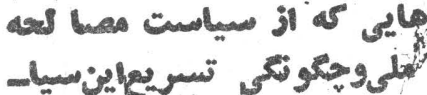
ست ارايه ميكنوهريه دئيل

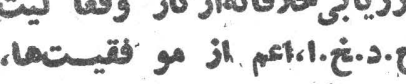

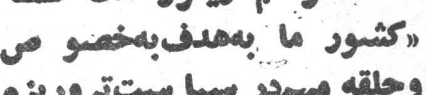

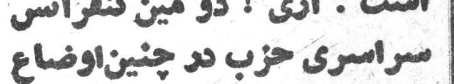

\section{$3 \div 914 \geq 92$}

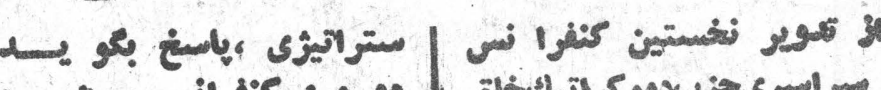

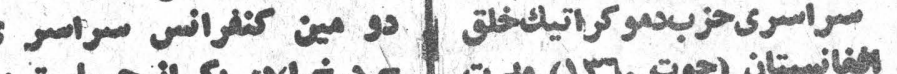

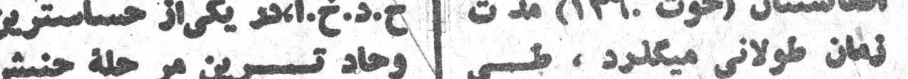

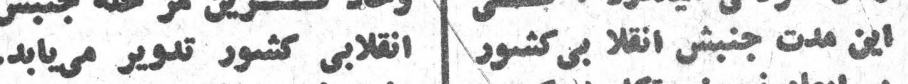

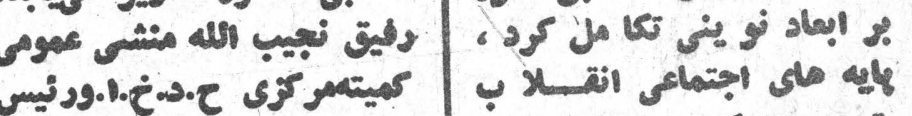

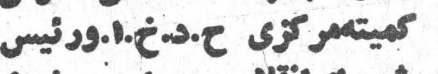

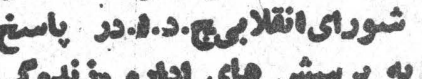

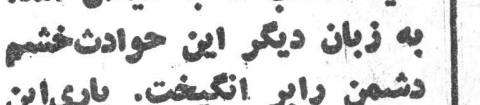

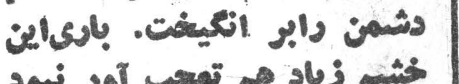

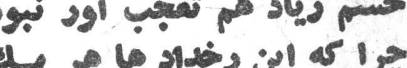

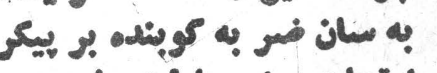

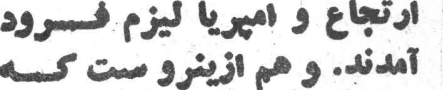

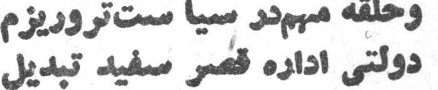

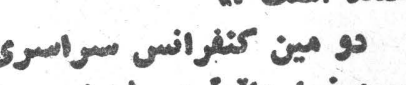

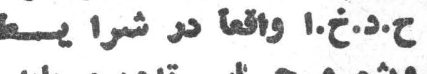

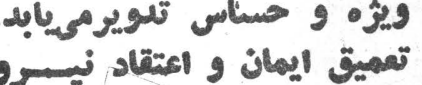

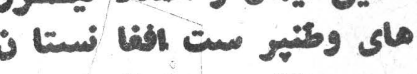

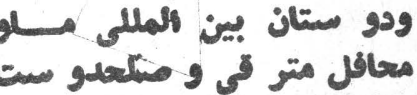

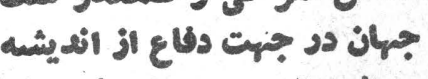

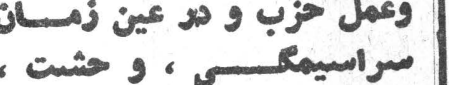

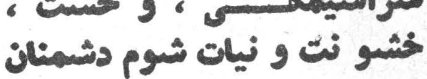

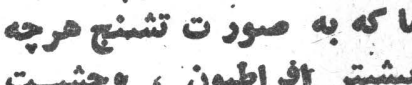

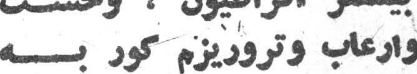

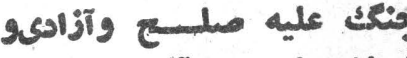

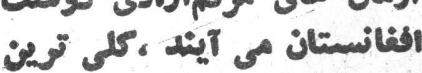

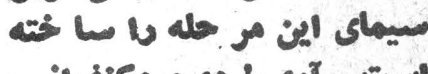

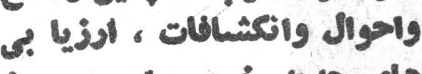

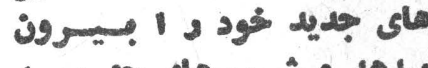

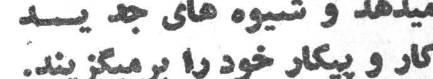

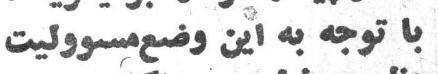

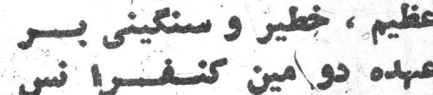

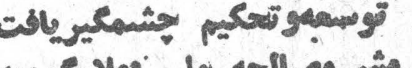

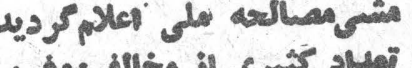

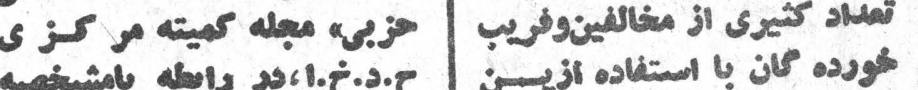
ون

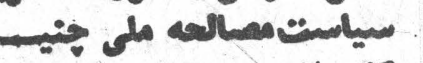

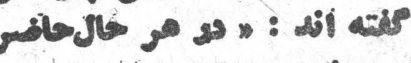

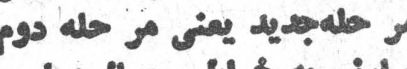

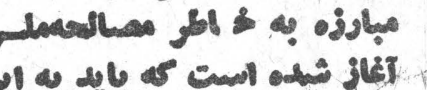

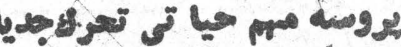

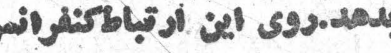

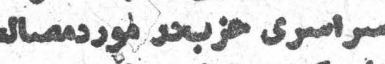

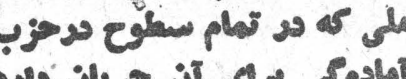

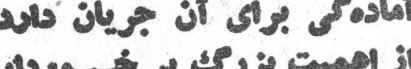

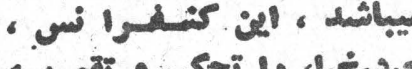

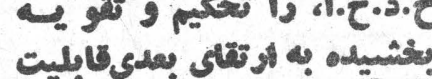

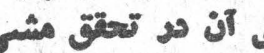

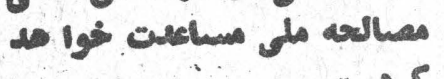

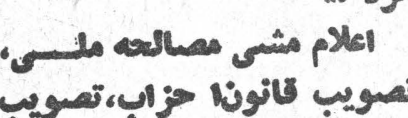

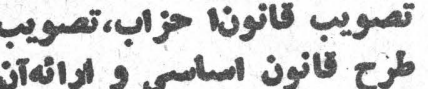

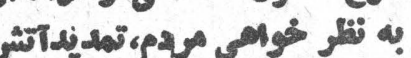
بس يك جأبه الز حوادث عثليم ونوين

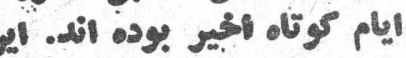

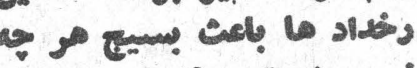

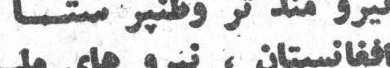

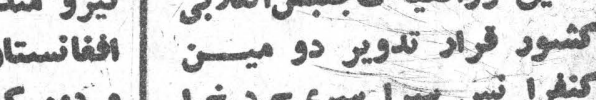

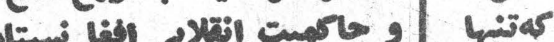

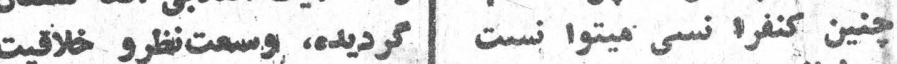

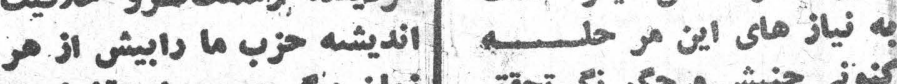

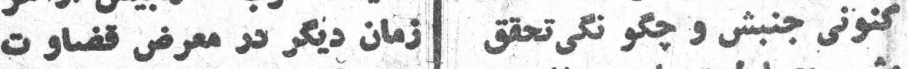

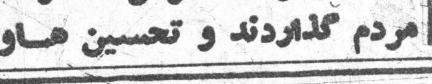

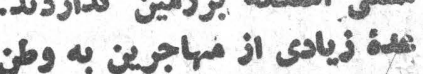

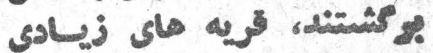

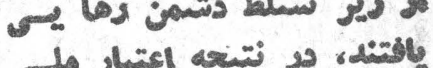

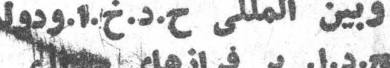

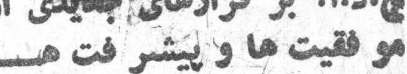

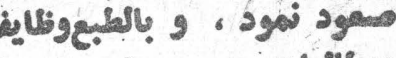

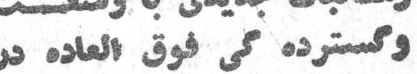

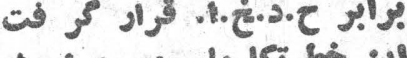

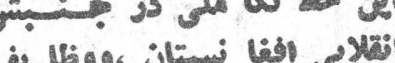

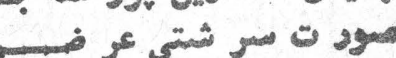

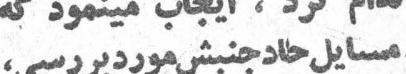

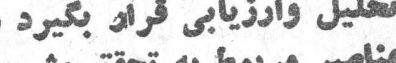

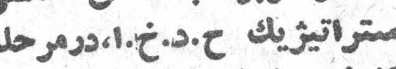

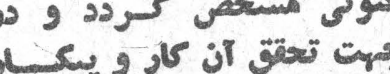




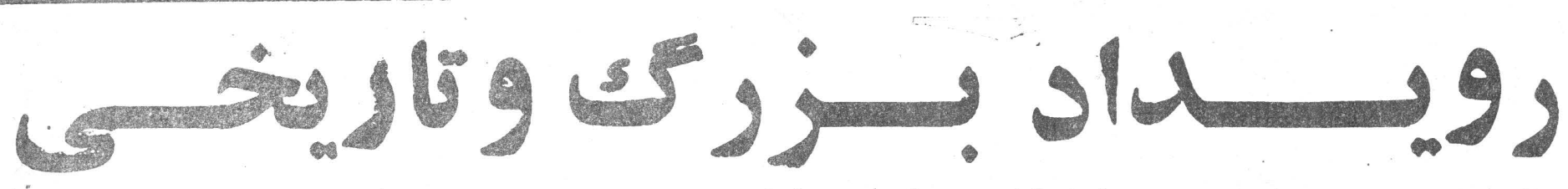

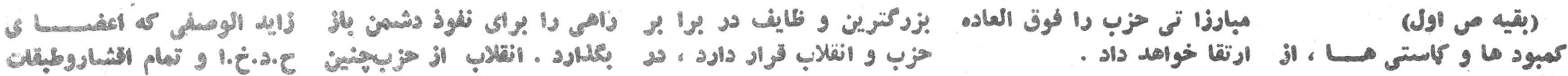

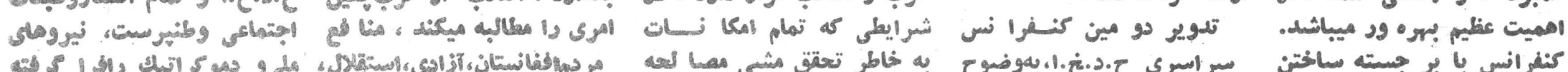

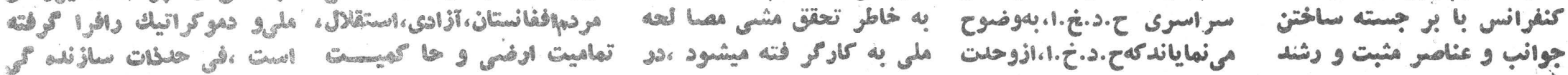

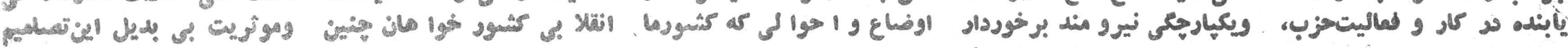

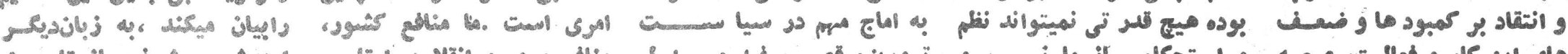

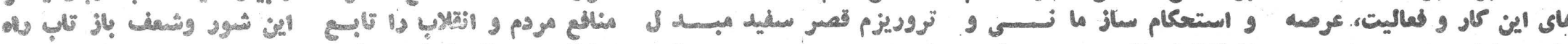

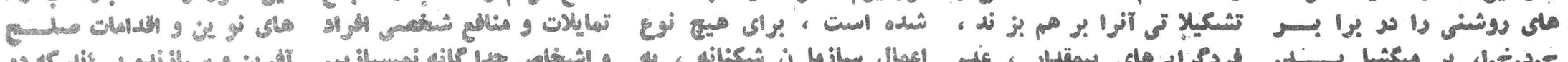

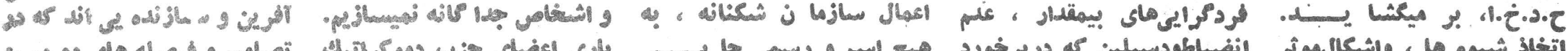

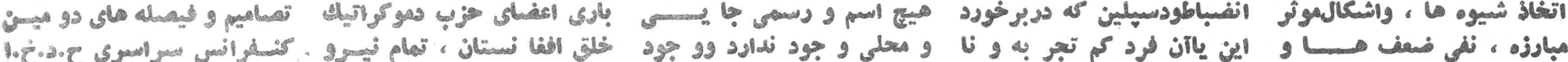

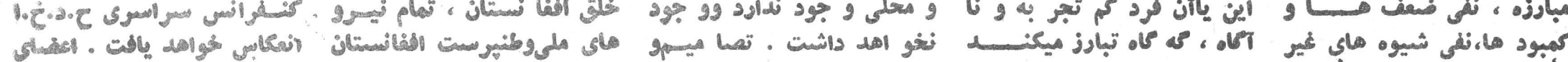

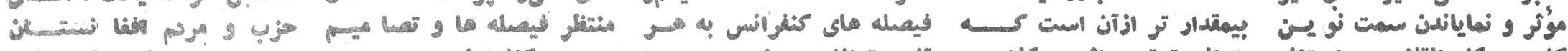

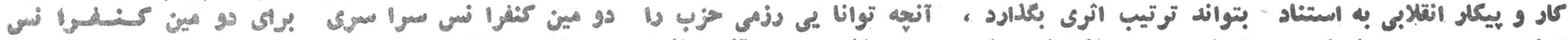

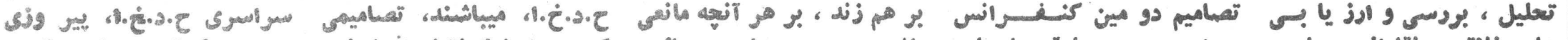

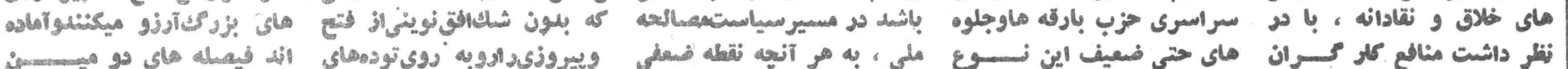

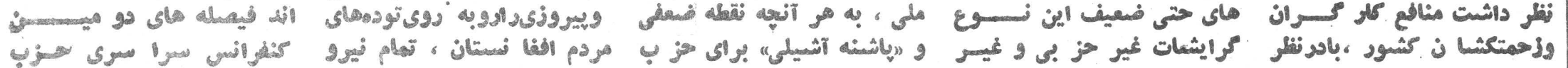

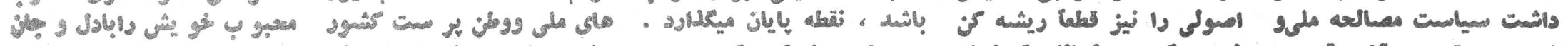

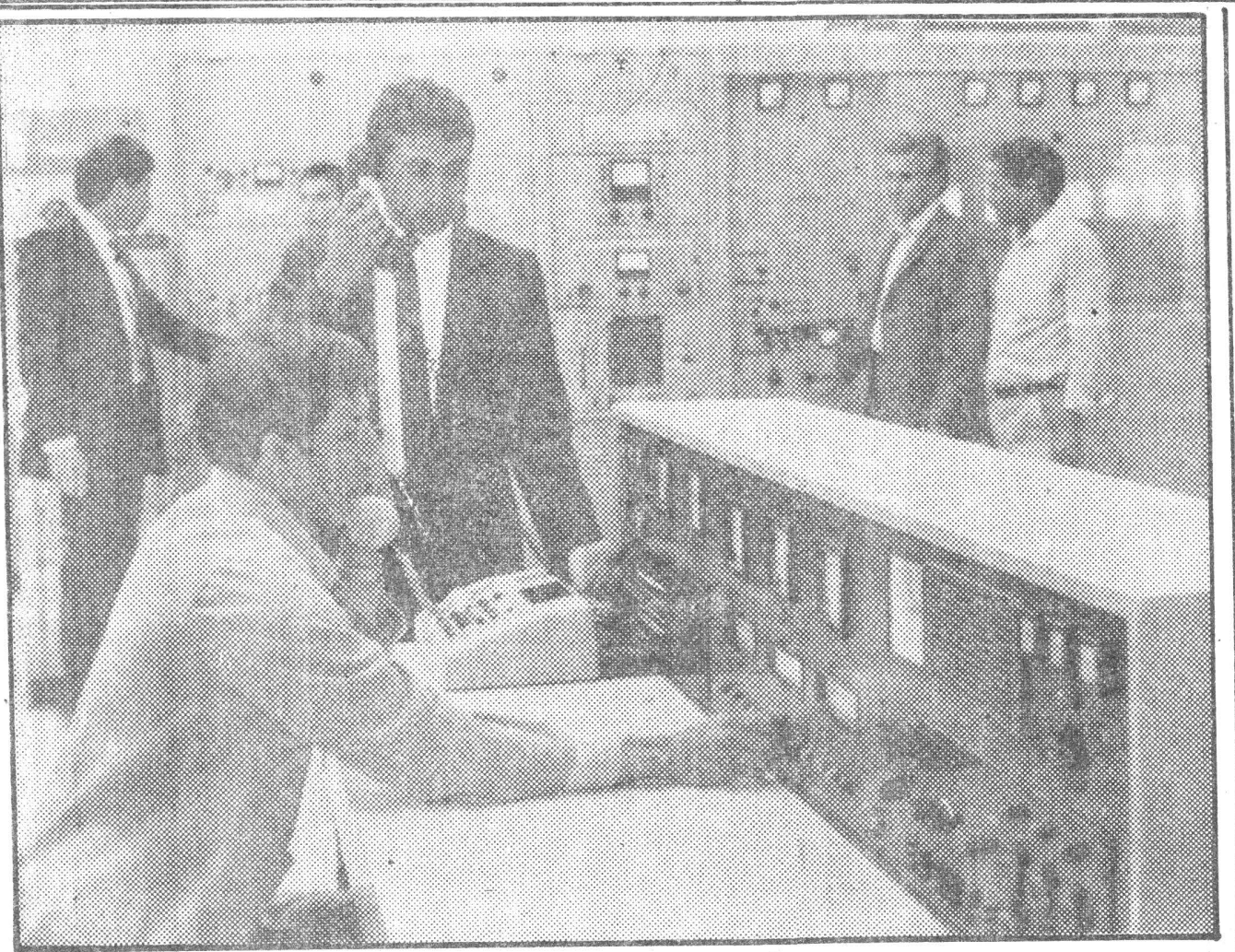

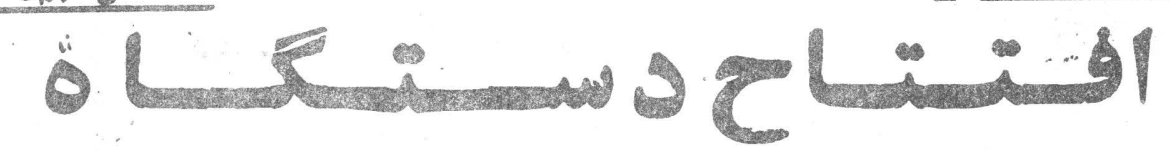

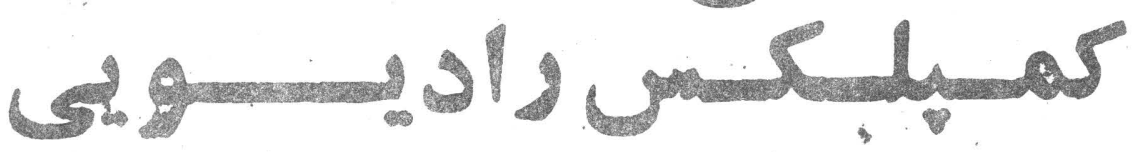

A

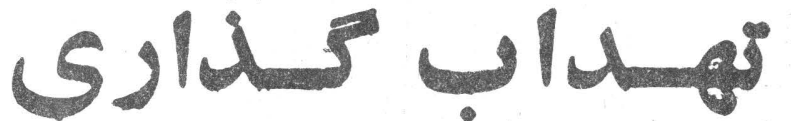 هو كز جديد تعليمى}

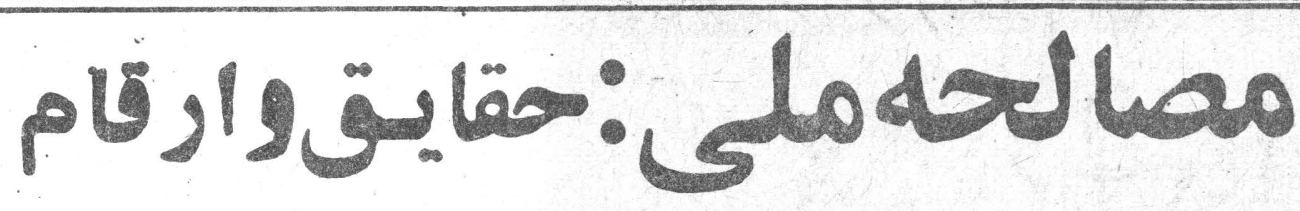

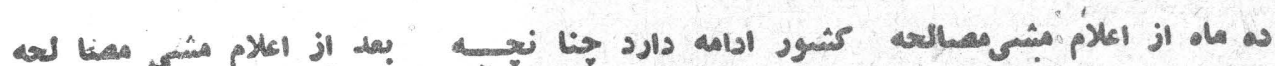

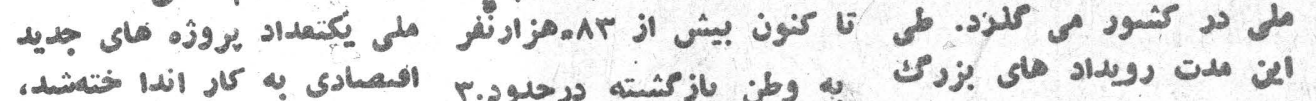

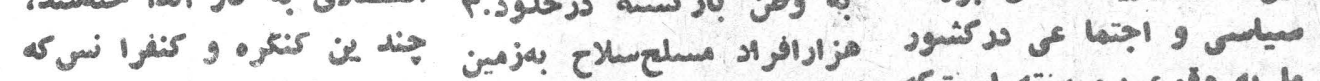

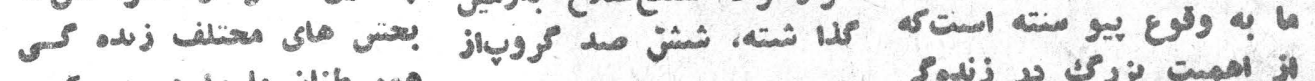

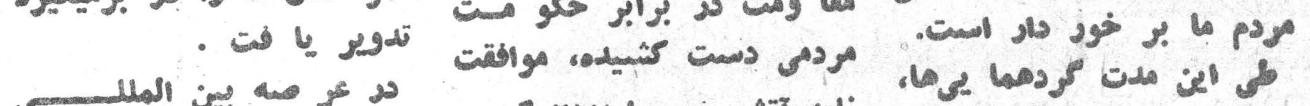

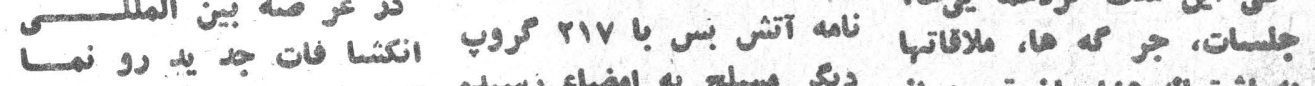

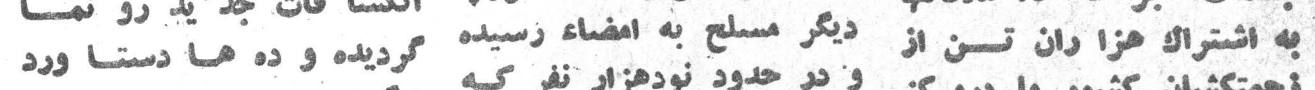

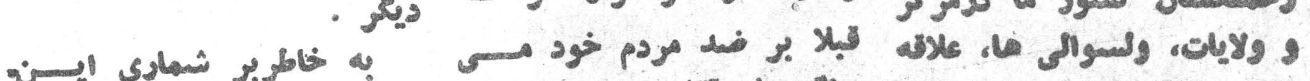

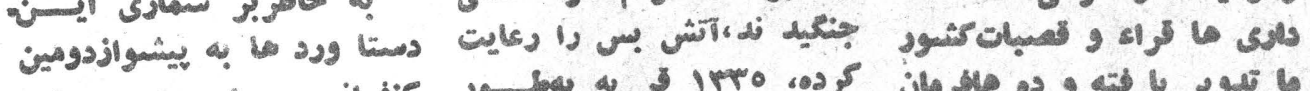

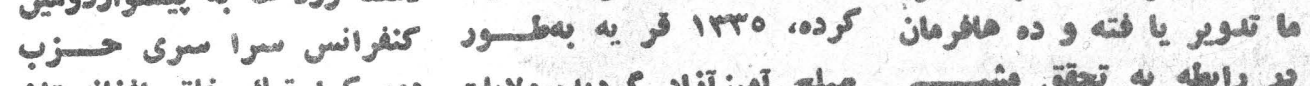

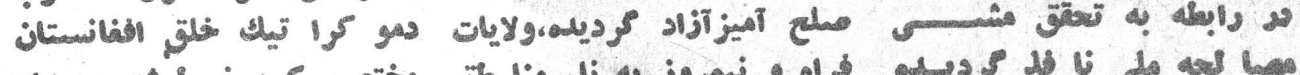

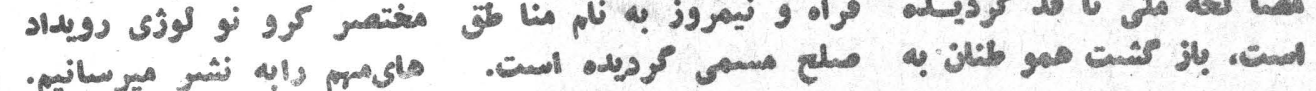
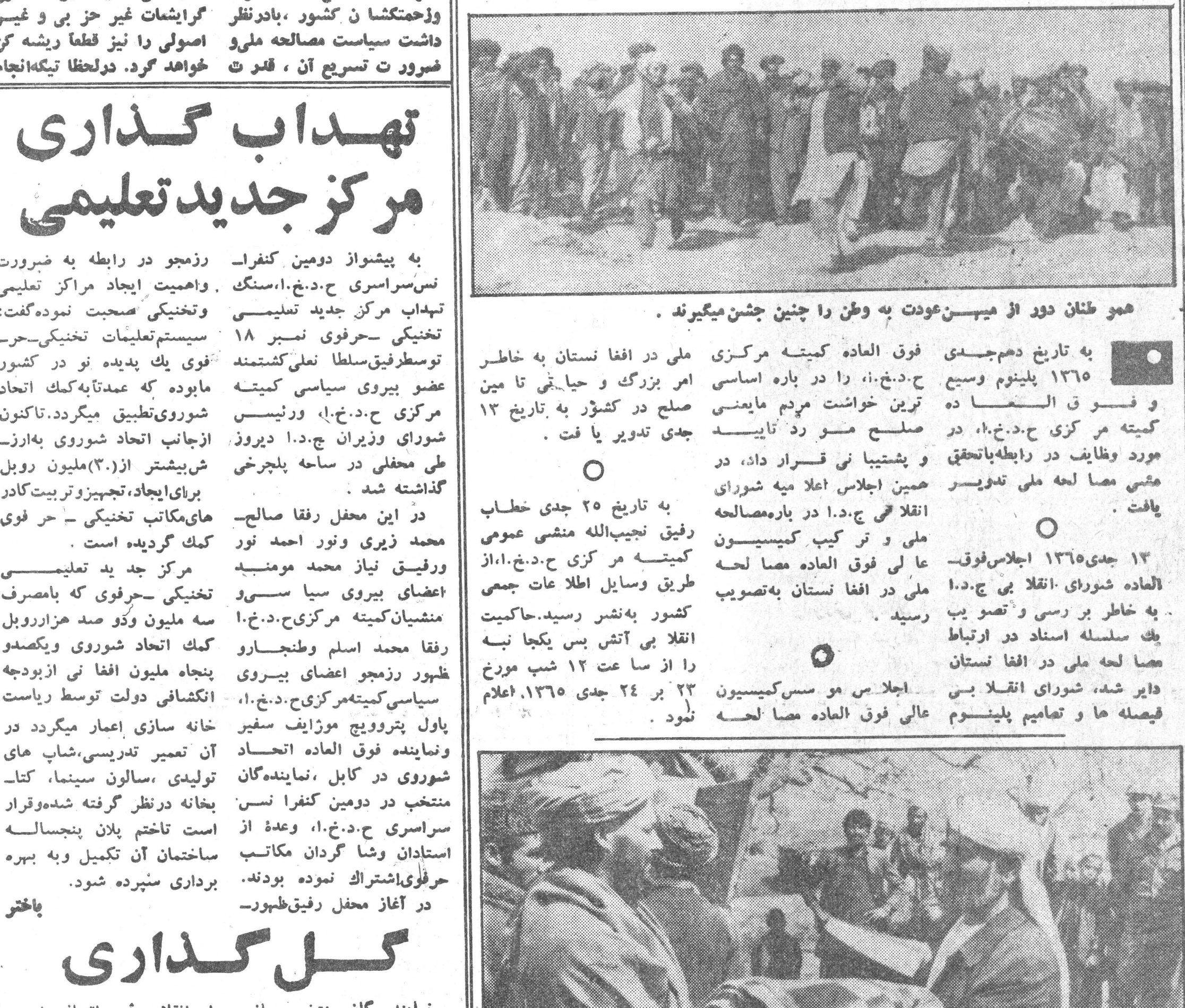

0

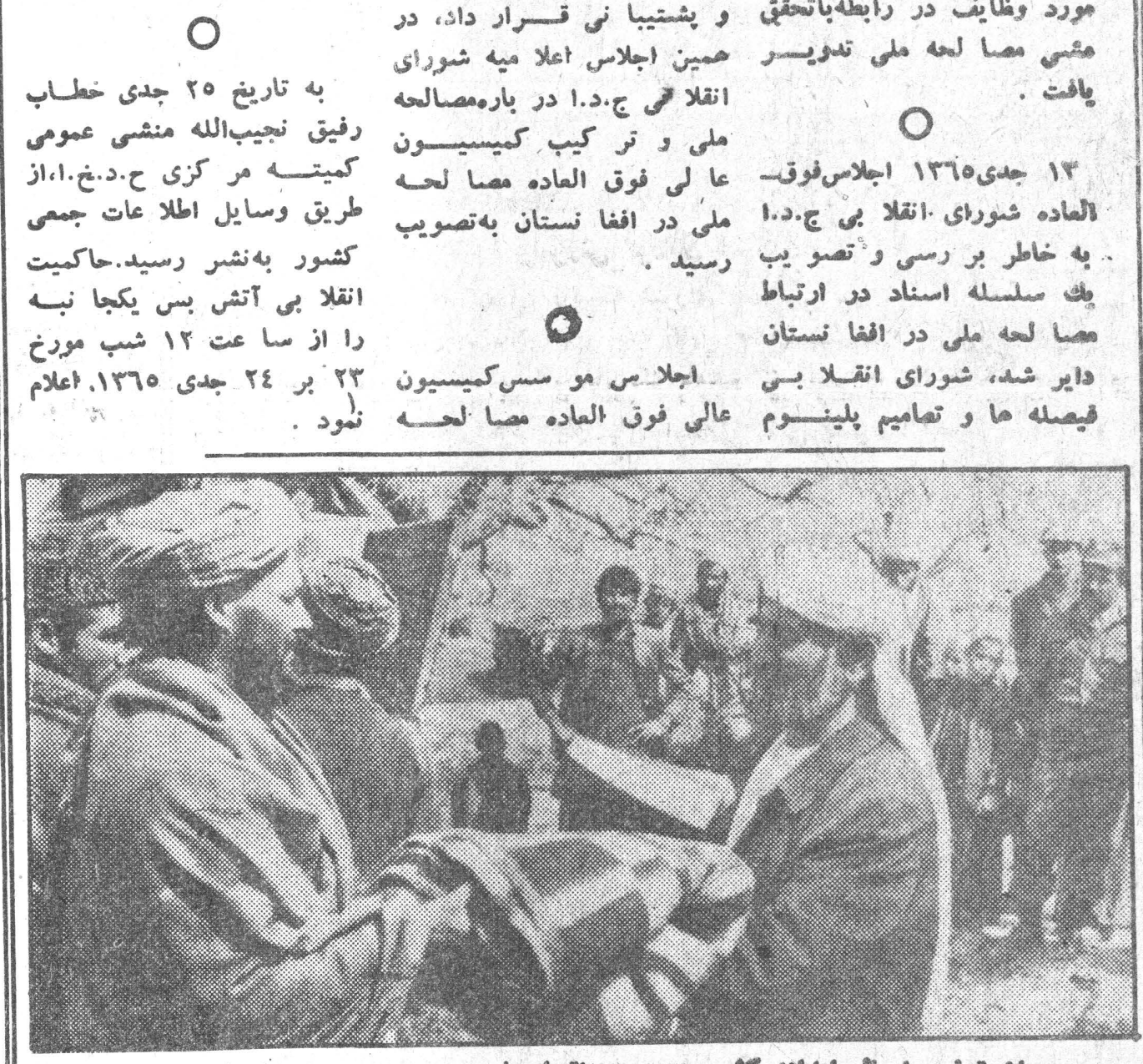

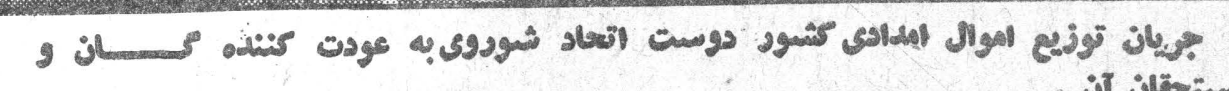

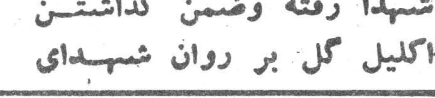

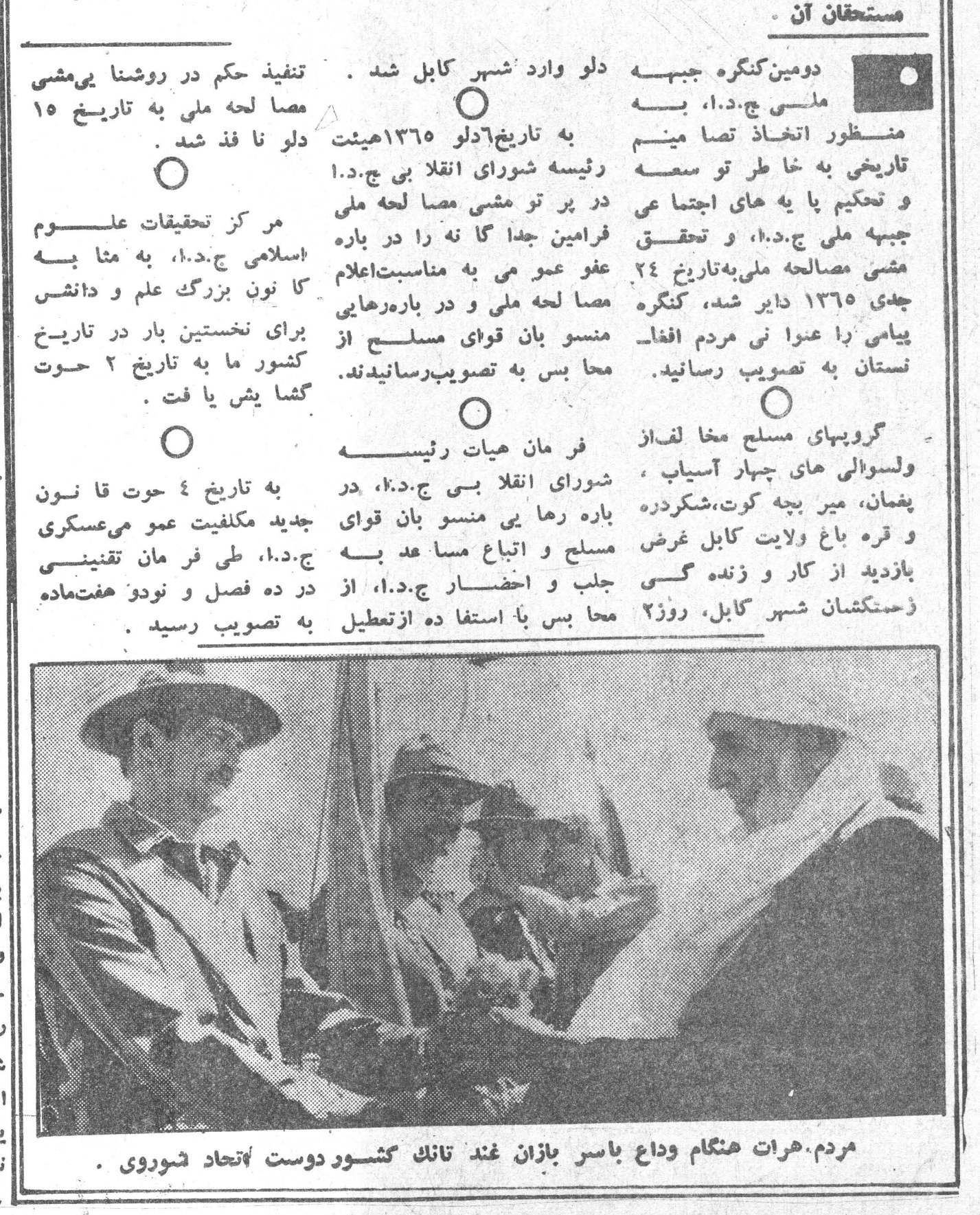




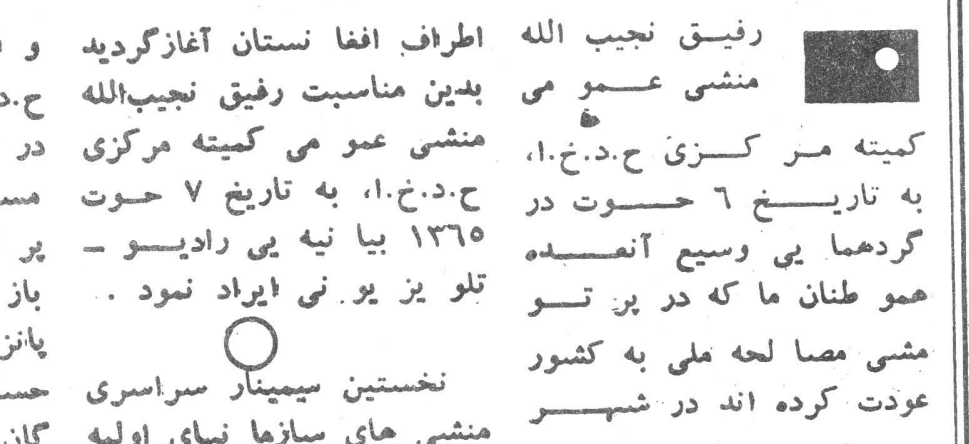

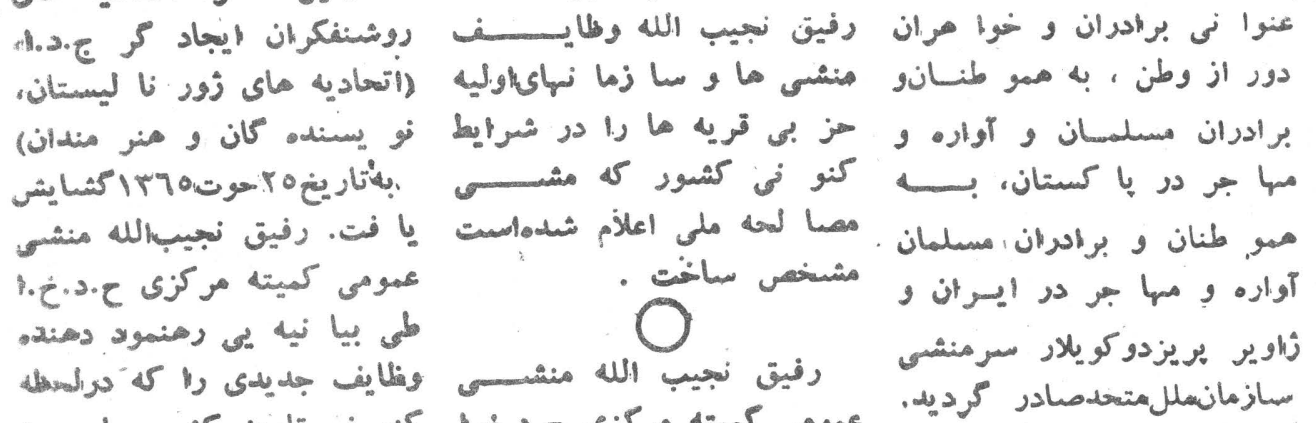

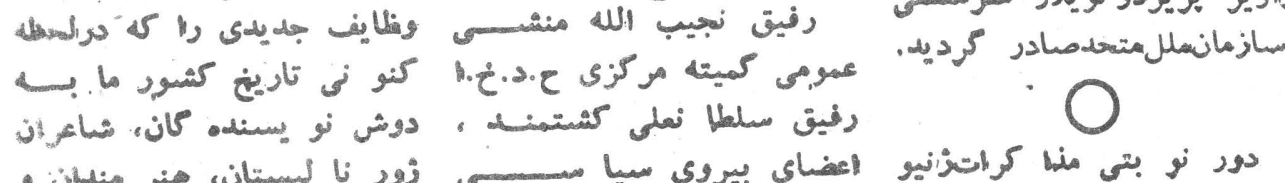

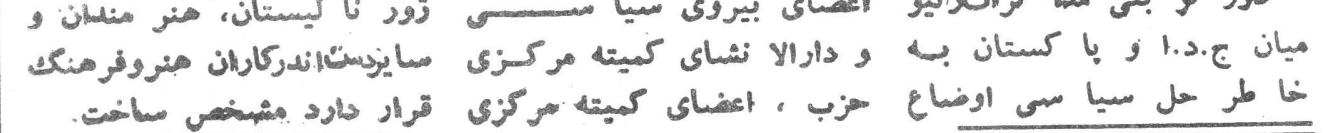

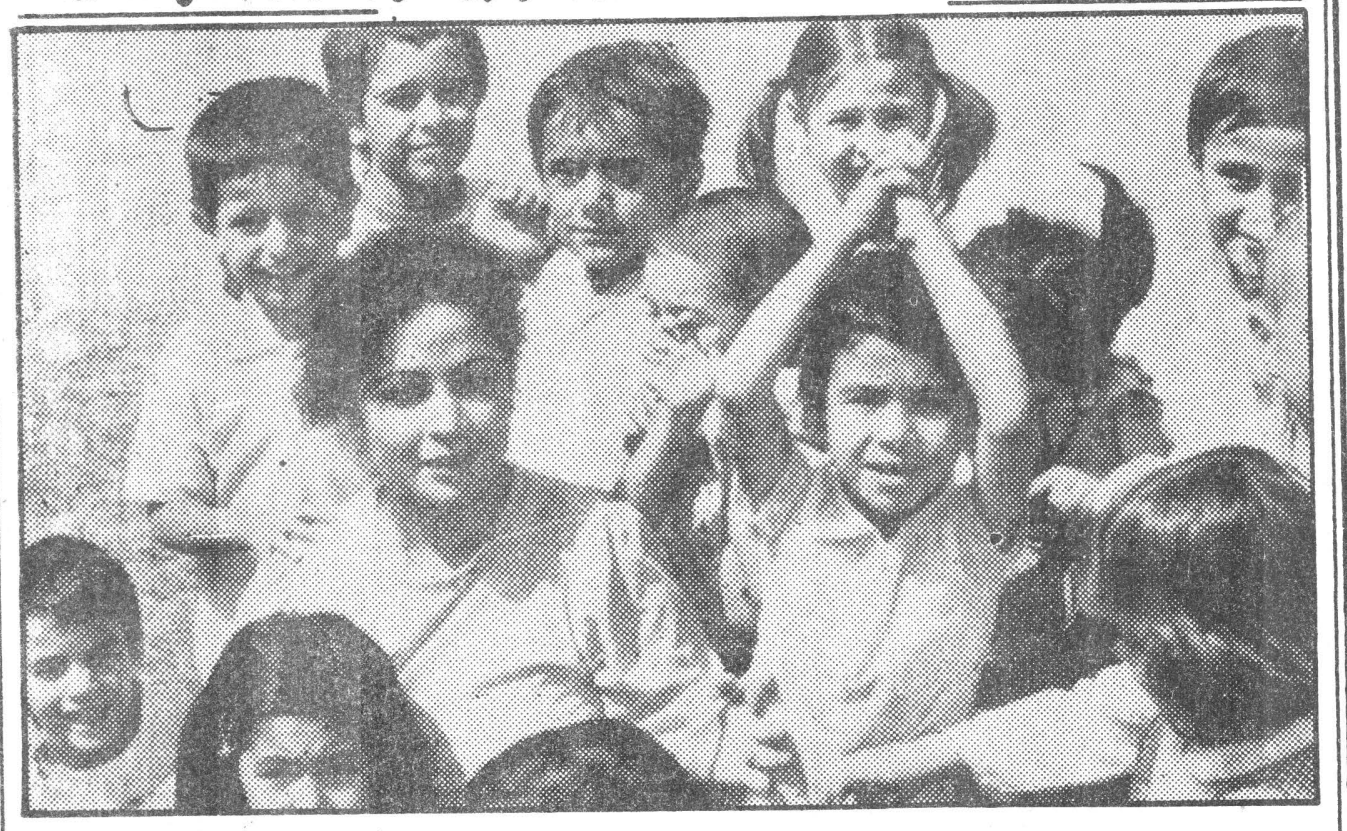

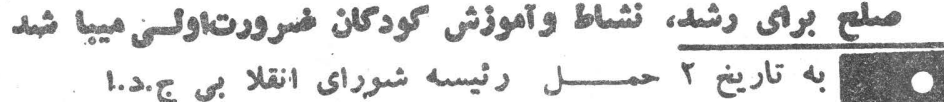

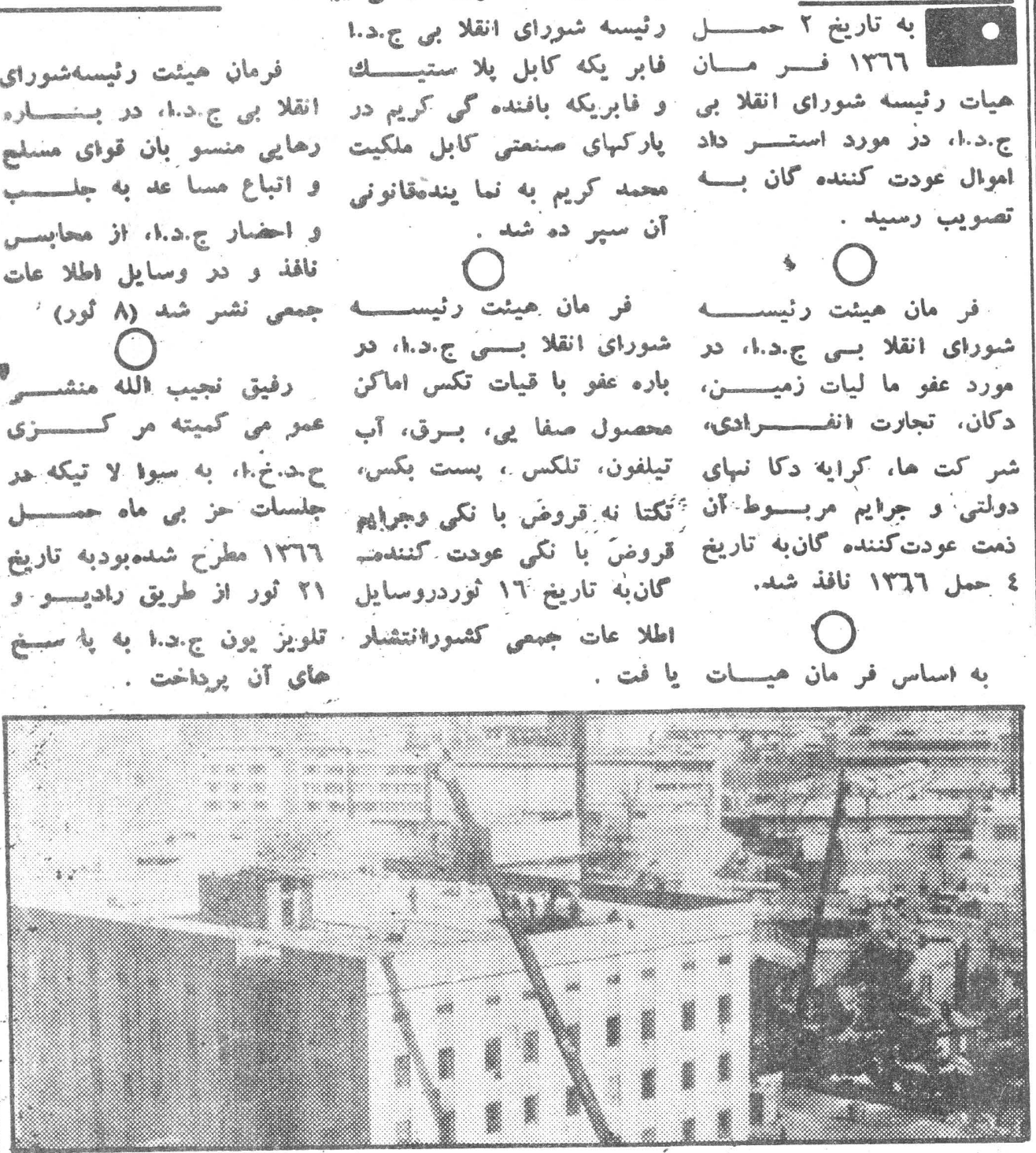

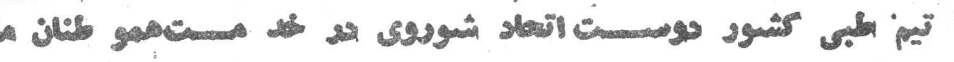

0

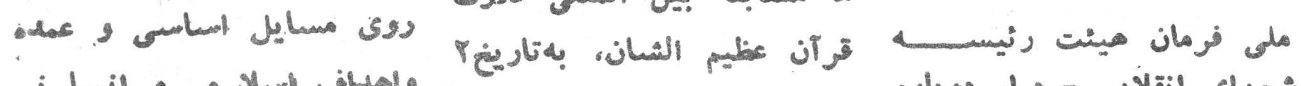

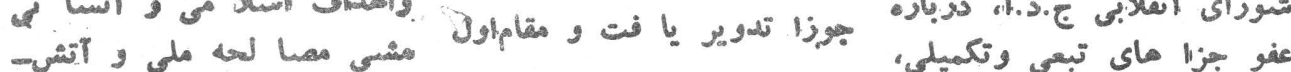

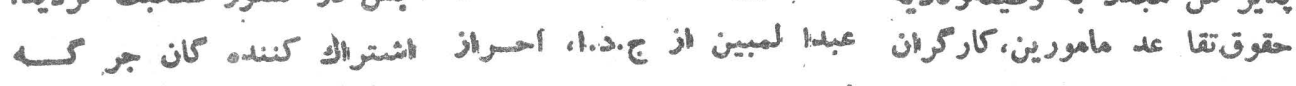

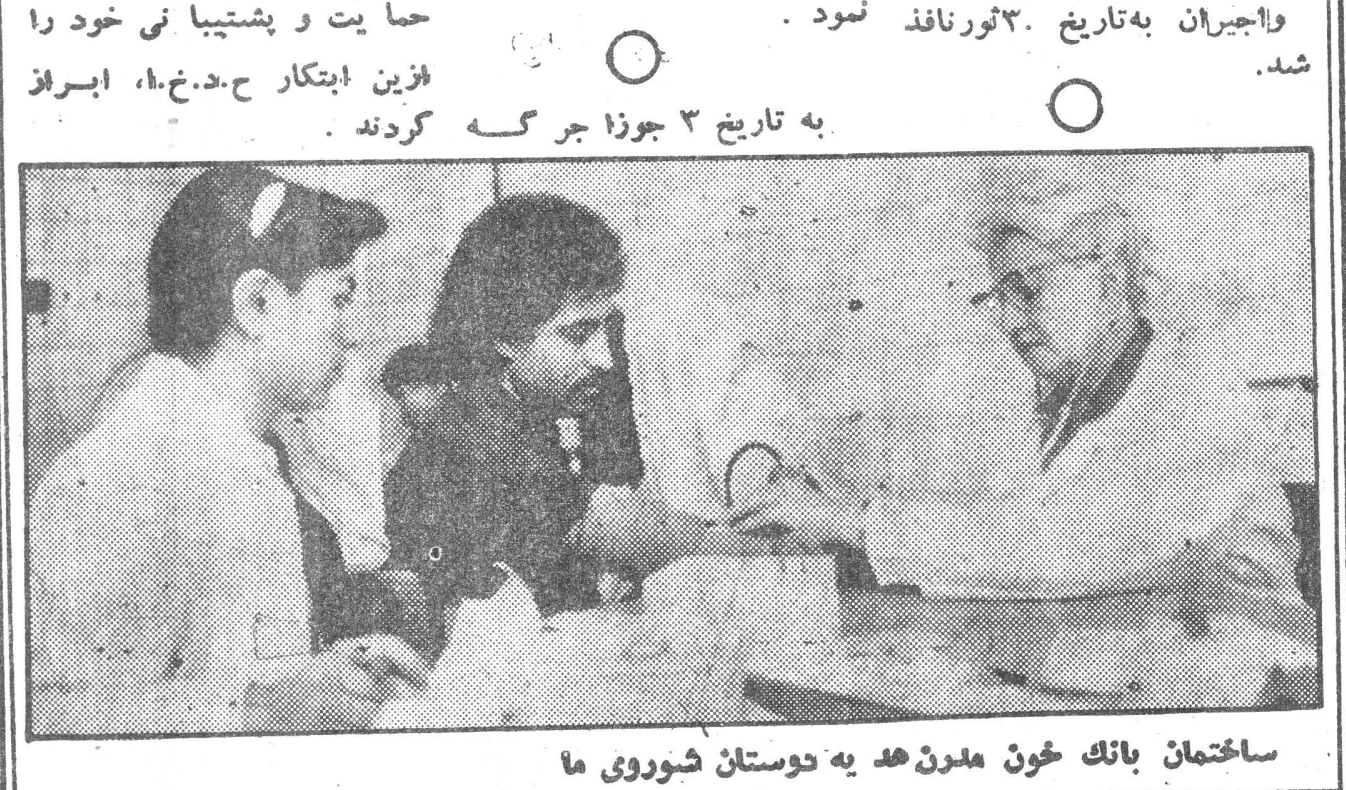

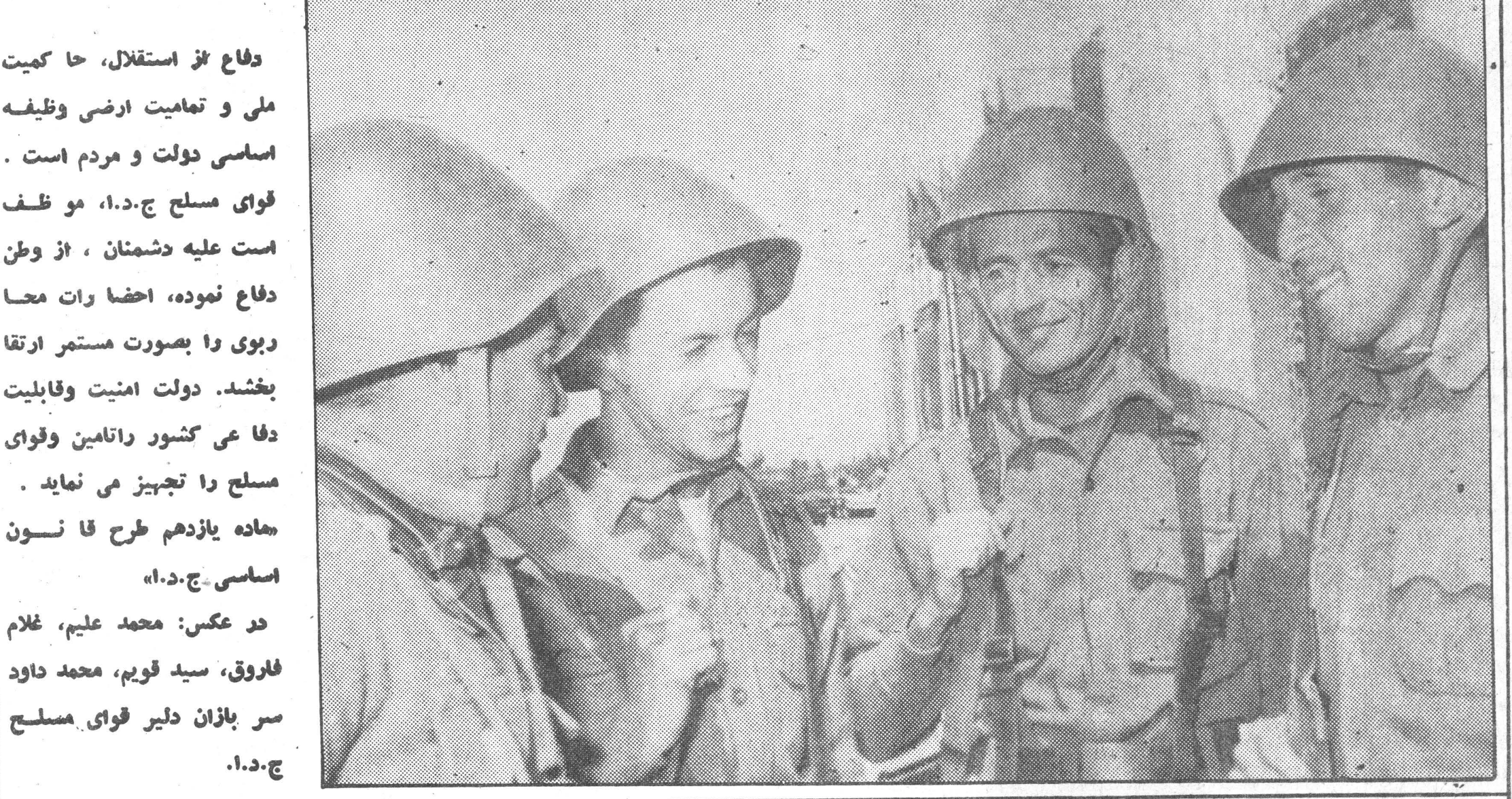

\section{و}

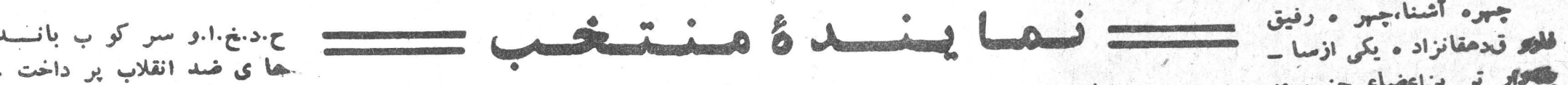

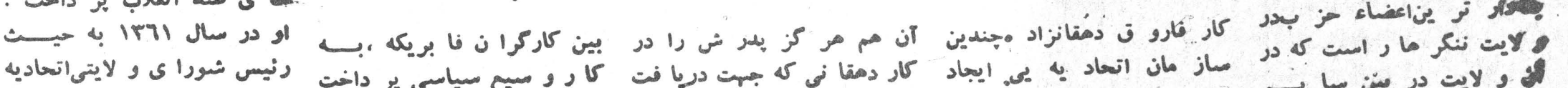

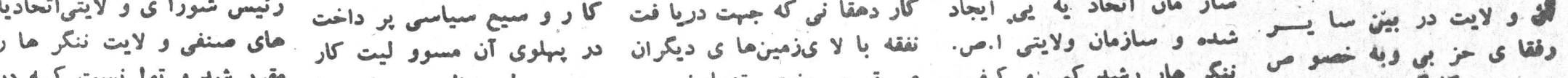

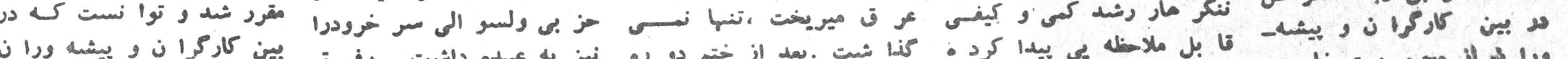

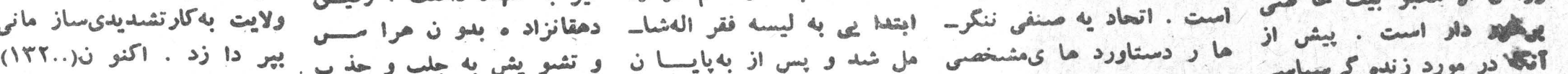

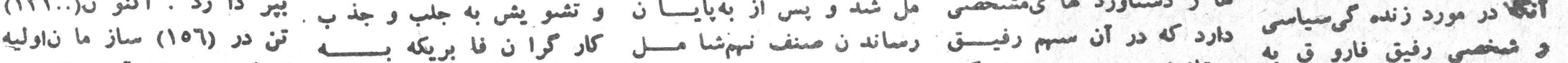

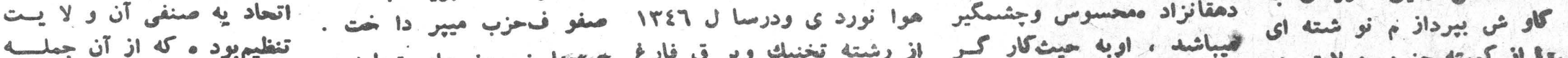

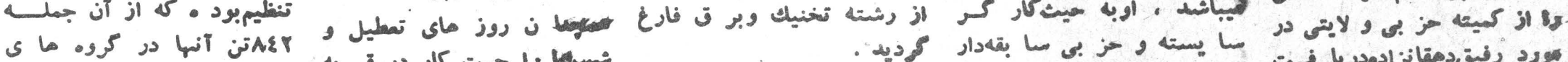

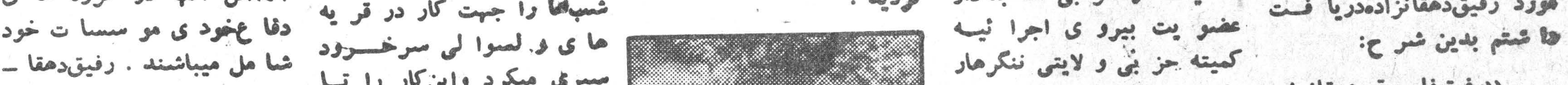

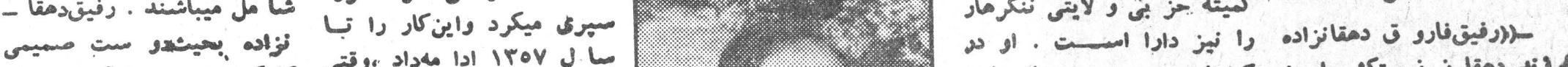

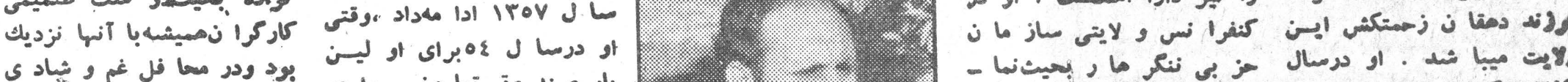

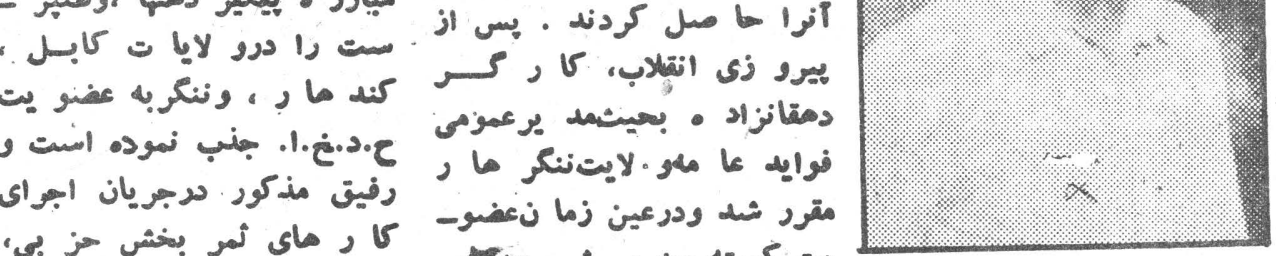

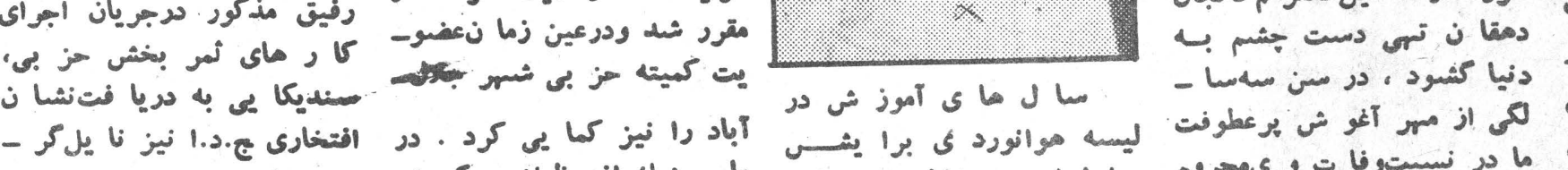

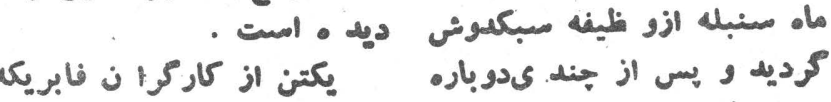

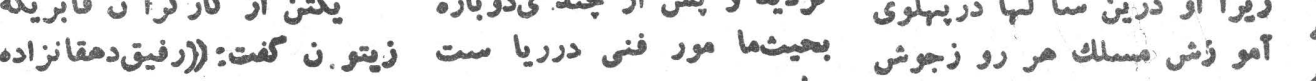

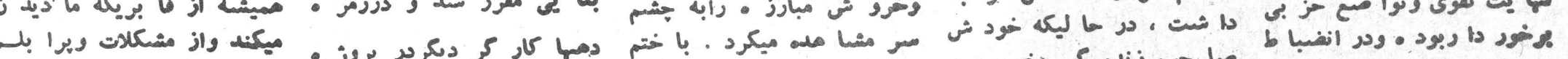

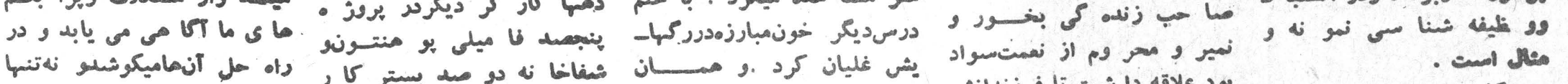

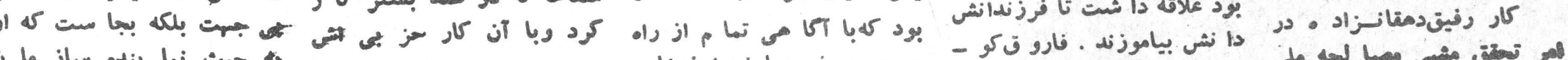

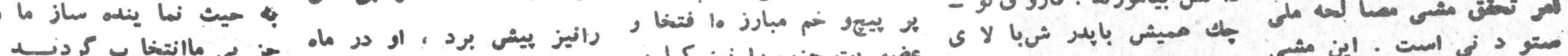

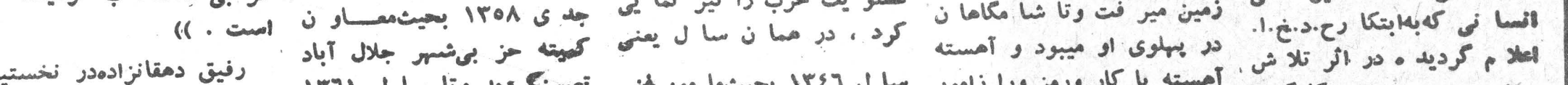

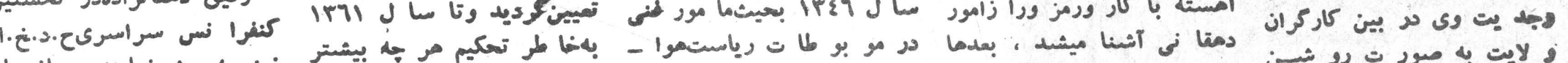

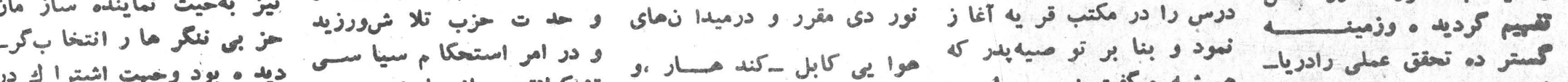

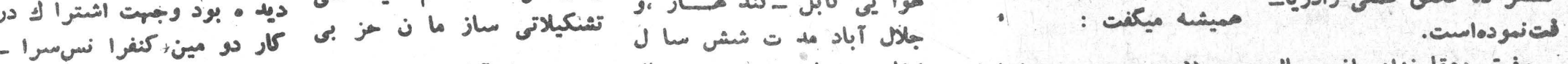

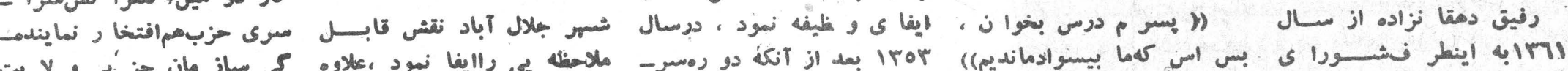

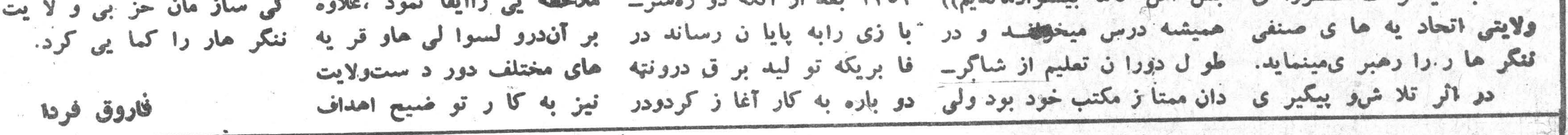

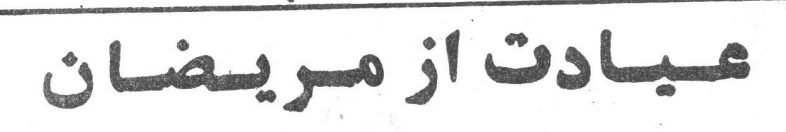

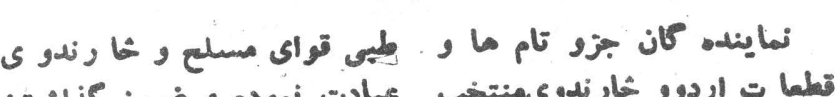

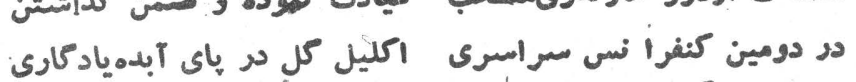

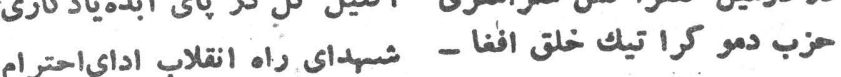

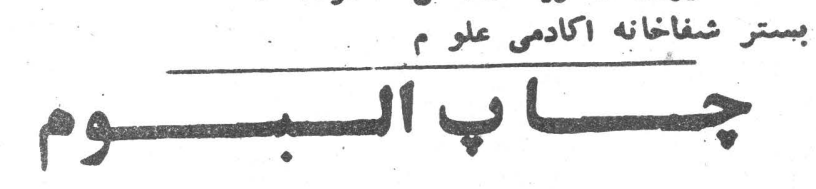

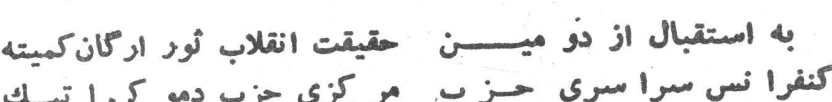

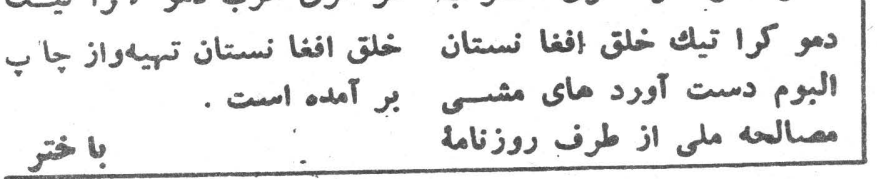

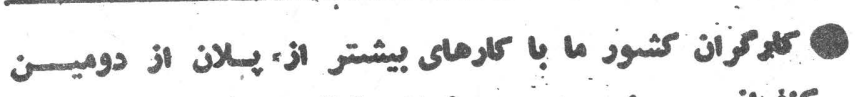

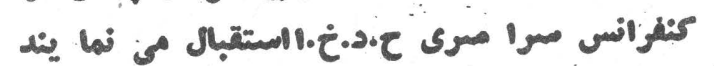

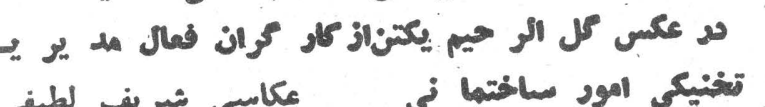

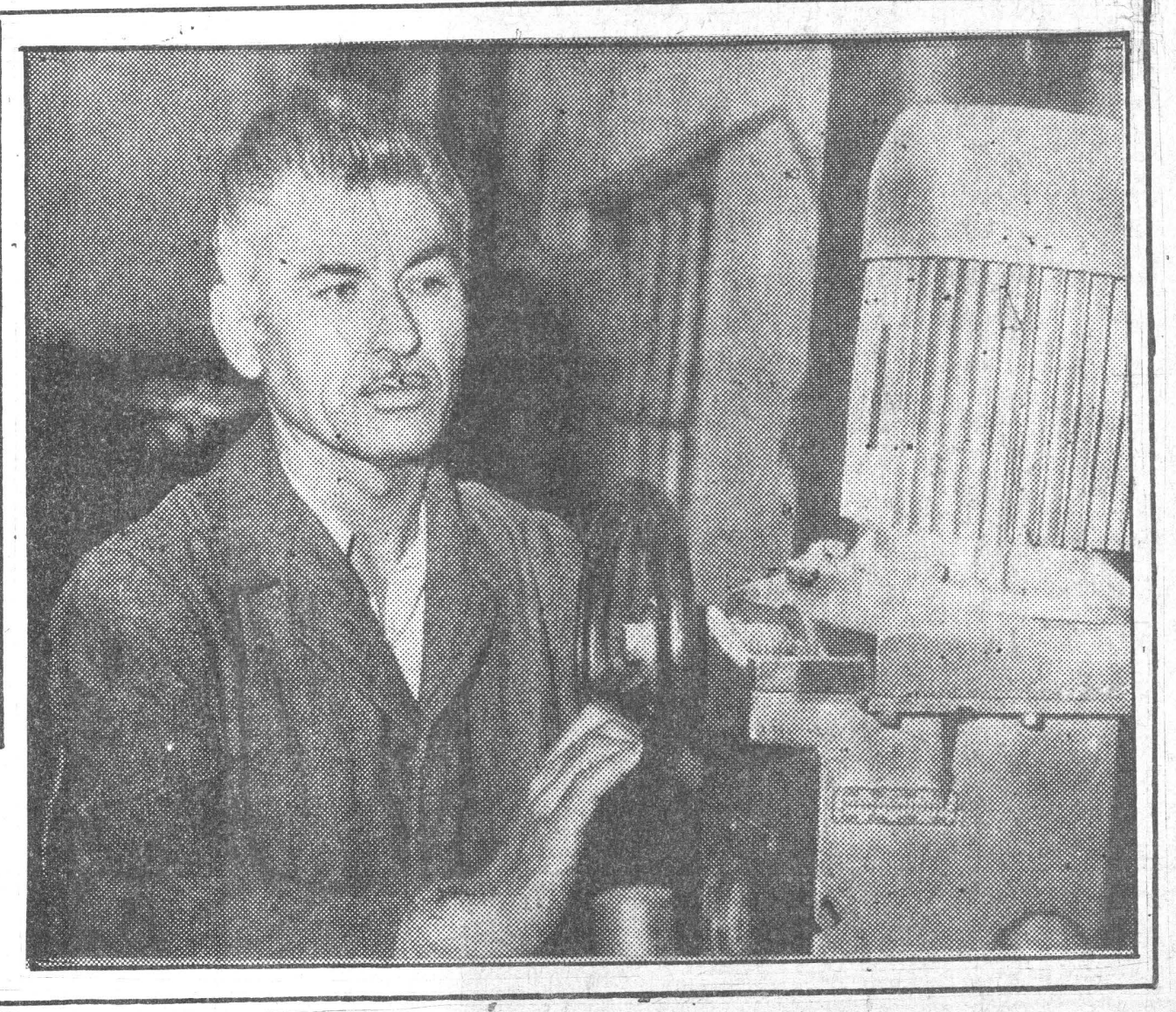




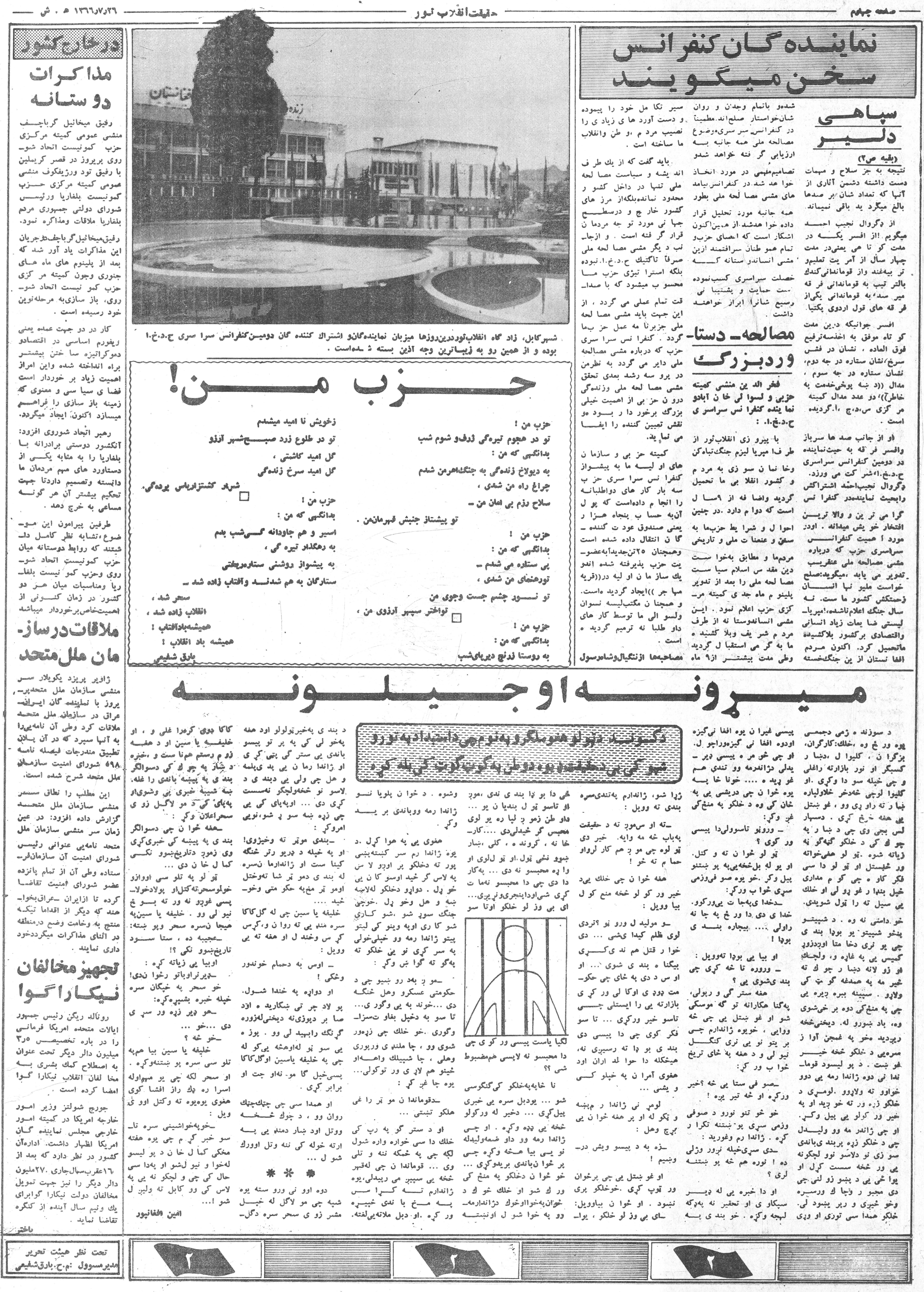

